Ročník XVII (2015), Číslo 3-4, s. 386-392/ Volume XVII (2015), Issue 3-4, pp. 386-392

(c) Mezinárodní politologický ústav / International Institute of Political Science

DOI: $10.5817 / C E P S R .2015 .34 .386$

\title{
Přemysl Rosůlek: Politický secesionismus \& etické teorie. Allen Buchanan a jeho kritici
}

\author{
Brno: Barrister\&Principal, 2014, 171 s. ISBN: 978-80-7485-037-0 \\ JAN BLAŽEK ${ }^{1}$
}

Předkládaná kniha Politický secesionismus a etické teorie: Allen Buchanan a jeho kritici je zajímavým př́spěvkem do české akademické debaty o dlouho opomíjeném fenoménu politické secese. Jeho uvedení do širšího akademického povědomí je o to podstatnější, čím více se politická secese stává jedním z rozhodujících témat (nejen) našeho bezprostředního okolí, at' už to byla dř́ve otázka Kosova a dalších balkánských regionů, nověji pak potenciální secese Skotska, Baskicka, Katalánska či Lombardie, události ve východoukrajinských oblastech a na Krymu či nejaktuálněji napětí v jihovýchodním Turecku. Autor předkládané publikace, Přemysl Rosůlek, působí na Západočeské univerzitě, kde se věnuje otázkám spojenými právě s tématem secese, zejména pak nacionalismu, Balkánskému regionu a etickým otázkám současné politické filosofie.

Kniha Politický secesionismus a etické teorie má do značné míry přehledový charakter. Jde ovšem i za rámec pouhé deskripce a usiluje o zhodnocení klíčových (anglosaských) normativních prístupů na poli politicko-filosofické analýzy secese. Důraz na etický rozměr secese, resp. etický pohled na fenomén secese, považuji za rozhodující prrínos české politické vědě, v níž stále dominují deskriptivní a explanatorní př́stupy zkoumání politických fenoménů.

Kniha se skládá ze čtyř kapitol, které jsou jasně strukturované a tvoří logický a koherentní celek. Autor v ní demonstruje téměř encyklopedické znalosti literatury zabývající se politickou secesí, at’ už v dílčích kapitolách nebo v rozsáhlém poznámkovém aparátu. Velmi zajímavým momentem je také sbírka tematických map a infografik ve střední části knihy, která dodává publikaci větší plasticity a čtivějšího rázu.

Hlavním čtyřem kapitolám předchází úvod, v němž se setkáme s drobnou chybou, nebot' název na titulní straně publikace neodpovídá názvu zmíněnému

1 Doktorand, Ústav mezinárodních vztahů, Nerudova 3, 11850 Praha 1, Česká republika / Institute of International Relations, Prague, Czech Republic. Contact: blazek@iir.cz. 
v úvodu (s. 11). Hlavním poselstvím úvodu je však stručné a jasné shrnutí, že jádrem a jakousi vůdčí linkou, která stmeluje předkládanou knihu, je remediální teorie secese Allena Buchanana, resp. její konfrontace s teoriemi národního sebeurčení a teoriemi plebiscitními, stejně jako konfrontace s komplexitou politické praxe.

V úvodu také autor jasně vymezuje základní výzkumnou otázku, která navazuje na výše zmíněné: je remediální teorie secese Allena Buchanana morálně ospravedlnitelná? Na tuto hlavní otázku navazují dvě dílčí podotázky. První se týká etických principů jednotlivých normativních př́istupů: která ze trí zkoumaných teorií je morálně ospravedlnitelná? Druhá podotázka pak usiluje o navázání na politickou praxi: je možné etické principy Buchananova prístupu nadřadit dalších dvěma teoriím (s. 12)? Nakonec úvod nabízí jasně vymezenou a elegantně popsanou strukturu knihy, stejně jako stručný, nicméně hutný výklad metodologie opřené o gadamerovskou hermeneutiku a komparativní politickou teorii.

Autor konstatuje, že obsah prvních dvou kapitol je ryze instrumentální a slouží pouze $\mathrm{k}$ co nejpřesnější definici fenoménu secese - chápané jako odtržení od státu -, resp. k vymezení rozhodujících kritérií pro komparaci daných normativních teorií, rozebíraných v kapitole třetí.

V kapitole první autor nabízí etymologické uchopení pojmu secese společně s vymezením mnohosti jeho významů, prričemž připomíná, že secese ve smyslu moderněpolitickém - státocentrickém - se začíná objevovat především až v 19. století (s. 19). Hlavní náplní kapitoly je však zejména vymezení hranic fenoménu ve vztahu ke spř́zněným pojmům a též přehled klíčových typologií. Autor pak kontrastuje pojem secese s dalšími blízkými fenomény jako sebeurčení, separatismus, iredentismus nebo vyloučení. $V$ jednoduchosti lze ř́ci, že secese je pouze jednou z forem sebeurčení; separatismus je formou oddělení od původního státu, ovšem při zachování jeho územní celistvosti; iredentismus je odtržením území od jednoho suverénního státu a připojení ke státu jinému; a nakonec vyloučení je nedobrovolné vyčlenění určitého území původního státu. První kapitola také nabízí chronologickou typologii členící př́pady secese na dekolonizační a posléze ty, které přicházejí v období tzv. nového světového řádu. Rozlišuje také secese jednostranné a konsensuální. Autor také nabízí diskusi vztahu secese k pojmům legality a legitimity. Nabízí taktéž kontextualizaci studia secese v současných sociálních vědách. Zdůrazňuje, že jeho kořeny spadají zejména do mezinárodního práva, a ačkoliv se dnes výzkumu secese věnuje celá řada disciplín, jeho nástup začíná teprve v období 70.-80. let 20. století, tedy v kontextu sociálních procesů vrcholení dekolonizace, štěpení dekolonizovaných států, rostoucích separatistických tendencí oblastí v západních zemích jako je Baskicko, Skotsko či Quebec, či fenoménu rozpadu postkomunistických zemí v 90. letech. 
$\mathrm{V}$ druhé kapitole autor pokračuje $\mathrm{v}$ deskriptivním trendu nastoleném v kapitole první a skrze rozbor existujících vysvětlujících př́stupů zkoumá možnou škálu prríčin secese a její průběh. Autor tak v krátkosti rozebírá př́stupy zabývajícími se dílčími problémy secese; zastoupeny jsou např. teritoriálné-ideologická dimenz̧e (Ivo D. Duchacek); etnicita, náboženství, beąprávi a sousedství (Crawford Young); secese jako disledek socio-bistorickébo procesu (Anthony D. Smith) či vatah mezi secesionistickými skupinami a ekonomickými podminkami (Donald L. Horowitz). V závěru druhé kapitoly autor vymezuje kauzální strukturu definice opřenou o sedmibodovou príčinnou souvislost potenciální secese vyvěrající z rozborů prvních dvou kapitol (s. 52). A na ní pak bezprostředně navazuje svou definicí secese jakožto komplexního a úspěšného odtržení:

„V důsledku deficitu ve vztahu mezi centrem a periferií se $\mathrm{v}$ politickém systému ustanoví politické hnutí, definované zpravidla kulturně či teritoriálně, které, podporované většinou obyvatel potenciálně secesionistického regionu, artikuluje záměr ustavit vlastní stát $\mathrm{v}$ hranicích území s argumentem oprávněného nároku na tento politický akt a na území regionu, vyhlásí nezávislost, ustaví mocenské orgány nového státu, vykonává kontrolu nad územím regionu a získává plnohodnotné uznání od existujících států, mezinárodních organizací i od státu, do něhož se skupina i s územím vyčlenila“" (s. 53).

Z této definice pak autor vyzdvihuje několik rozhodujících kritérií, která slouží jako pilíre komparativního rámce pro analýzu normativních teorií - tedy teorie remediální, národního sebeurčení a plebiscitní. Těmito kritérii jsou 1) legitimita secesionistického axiomu, 2) legitimita práva na secesi, 3) legitimita teritoriální dimenze, 4) etika mezinárodního práva a konečně 5) etika uznání států (s. 53).

Ačkoliv autor přiznává, že úkol prvních dvou kapitol je ryze instrumentální, je namístě se ptát, zdali rozmáchlá deskripce není cílem sama o sobě, právě z toho důvodu, že dané téma není v našich končinách přiliš známé. Pokud tomu tak je a jde tedy o vyjasnění tématu pro otevření dlouhodobější akademické diskuse, pak je možné úvodní dvě kapitoly chápat jako přínosné. Pokud mají naopak opravdu sloužit ryze instrumentálně, je otázkou, nakolik bylo nutné je pojmout opravdu takto honosně a zdali jich bylo opravdu třeba pro vymezení srozumitelné a dobře podložené definice. Přece jen, obě kapitoly - zejména kapitola druhá, která působí kvưli nedostatku prostoru kuse a útržkovitě - dodávají publikaci spíše ráz diplomové práce než odborné publikace zkušeného akademika s kritickými normativními cíli. Budí tak dojem zbytečného balastu okolo skutečného jádra knihy, na které čtenář čeká 55 stran.

Klíčovou část knihy tvoří třetí kapitola nazvaná „Secese a legitimita - normativní teorie secese“", ve které se konečně čtenář dočká toho, co slibuje titul knihy. Kapitola je uvozena krátkým politicko-filosofickým přehledem, kde autor demonstruje neochotu politické filosofie zabývat se tématem secese. Krátký úvod 
uzavírá připomenutím, že tématem se secese stává až v období 80 . let 20. století. Třetí kapitola je rozdělena do tř́ podkapitol, přičemž každá na základě výše zmíněných kritérií rozebírá jeden ze tří zmiňovaných normativních proudů: a) Remediální teorie secese Allena Buchanana, b) Teorie národního sebeurčení a c) Plebiscitární teorie.

Jádro Buchananova př́stupu - který je vưdčí osobností na poli akademické reflexe secese - tvoří jasné stanovisko apriori odmítající jednostrannou secesi, až na výjimky odtržení se $v$ prŕpadech: a) hrubého, systematického a dlouhodobého porušování lidských práv, př́padně fyzického ohrožení členů skupiny, které může mít až charakter genocidy; b) předchozí svévolné anexe suverénního státu a c) konsensuální secese. Buchanan dodává ještě několik dalších bodů, které ovšem dle něj neobstojí jako samostatná kritéria legitimizující jednostrannou secesi.

Buchanan staví svou zásadní antisecesionistickou pozici na snaze uchovat $\mathrm{v}$ mezinárodním řádu co největší stupeň stability a míru. Kromě obavy z toho, že odtržená území liberálně demokratických států nebudou hájit základní liberální hodnoty, má Buchanan strach z otevření Pandořiny skříňky nekončícího řetězu secesí, které vyvolají chaos a destabilizaci mezinárodního systému (s. 60). Buchanan věŕi, že „výkonné a spravedlivé státy jsou schopné vynutit dodržování funkčního právního řádu, zajistit fyzické bezpečí jednotlivcům a skupina, bránit hodnoty jednotlivců a skupin a umožnit občanům výkon jejich práv na politickou participaci“ (tamtéž). Skrze odpor vůči secesi brojí Buchanan proti touhám po homogenizaci a naopak věří, že $\mathrm{v}$ hranicích konstitučních demokracií lze hájit diverzitu, pluralismus a sebeurčení. Zvláštním paradoxem vztahujícím se k Buchananovu prrístupu k území a hranicím je skutečnost, že sám reflektuje krvavou historii většiny států, resp. jejich hranic, a přesto volá po normativním primátu uchovávání jejich současné podoby.

Druhá podkapitola je věnovaná rozboru teorií národního sebeurčení. Jak autor uvádí, jejich kořeny vychází z komunitaristické kritiky liberalismu, které ve svém atomizovaném pohledu na subjekt přehlíží roli politických komunit, zejména národních.

Pro autory jako David Miller představuje národ morální společenství, zejména díky sdílené kultuře a vzájemně uznávaným závazkům a též ochotě chránit společné národní zájmy, navzdory vědomí sociálně konstruovaných (B. Anderson) a často mytických kořenů národních společenství. Margaret Moore pak legitimitu národa ilustruje na metafoře rodiny a tvrdí, že morálně ospravedlnitelný je jen tehdy, pokud není hierarchický, exkluzivní a despotický. Autoři teorií národního sebeurčení se ovšem vyhýbají ryzímu nacionalismu. Určování hranice mezi legitimním patriotismem a zavrženíhodným rasismem je však jedním z problémů těchto prŕístupů. 
Probíraní autoři také vymezují ty formy národa, které si stát zaslouží a které nikoliv, a tvrdí, že právo na secesi mají jen některé tzv. separované národy (národy s jasně separovanou identitou od majoritního národa; např. Kurdové v Turecku), na rozdíl od imigrantské skupiny, etnicky smíšeného regionu a národní menšiny s duální identitou. Podle Millera má separovaný národ nárok na secesi, pokud splní podmínky oprávněného nároku na teritorium, relativní homogenity secesionistického regionu a principu distributivní spravedlnosti. Miller neprosazuje, aby každý národ měl vlastní stát, který nepovažuje za jedinou cestu sebeurčení. Rosůlek také nabízí kritiku tohoto proudu na Buchananovu adresu, kdy je mu vyčítána nejednoznačnost a nekoherence velmi omezených možností secese. Stejně v opačném gardu reflektuje Buchananovu kritiku teorií národního sebeurčení, navazující na obavy zmíněné výše. Buchanan má strach, že takto legitimovaná secese povede $\mathrm{k}$ vlně vzedmutí etnonacionalistického násilí (s. 88). Dále zpochybňuje jasné hranice národů a etnolingvistické pojetí národa, zdůrazñuje flexibilitu a dynamičnost kultur a v neposlední řadě má obavy z potlačování pluralismu a expanze rasistické verze nacionalismu.

Posledními z rozebíraných teorií jsou ty plebiscitní. V jádru jejich uvažování stojí zejména princip sebeurčení, který ovšem není limitován poměrně úzce vymezeným (legitimním) národním společenstvím, nýbrž je vázán na tzv. teritoriálně kompaktní skupiny, které mají za sebou historii „kontinuální existence jako distinktivní entity, které samy sebe takto vnímají“ (s. 94). Za takové entity považují někteř́ autoři dokonce i města. Autoři jako Harry Beran nebo Daniel Philpott pak dodávají další liberálně demokratické principy, v nichž ukotvují nárok na sebeurčení, at' už se jedná o Beranovu svobodu nebo Philpottovu kantovskou autonomii.

Plebiscitární teorie jsou ze všech zmíněných „,nejlibertariánštější“, čili kladou nejméně normativních překážek praxi secese. Tyto př́stupy se ostře vymezují vưči státocentrickému předpokladu, který platí u většiny teoretického uvažování o tomto fenoménu. Např́klad Harry Beran tvrdí, že legitimitu pro secesi má každá výše zmíněná skupina, která o ni usiluje, za předpokladu, že je secese morálně a prakticky uskutečnitelná. Ačkoliv ji podmiňuje dalšími dílčími principy - jako např́klad právo na secesi od většinové oblasti či liberálně demokratický charakter odtržené oblasti -, tak v porovnání s dvěma výše zmíněnými př́stupy se jedná o proud $\mathrm{k}$ jednostranné secesi zdaleka nejvstřícnější. Na rozdíl od dvou výše zmíněných proudů nevyžadují tito autoři a autorky legitimní nárok na území a jejich postoj $\mathrm{k}$ hranicím je velice flexibilní. Plebiscitární př́stupy podkopávají tendence na naturalizaci a reifikaci současných hranic.Jako jedna z klíčových výtek ve vztahu $\mathrm{k}$ Buchananovi zaznívá, že jeho volání po míru a stabilitě není o nic lepší než volání po sebeurčení, a jedná se tudíž jen o hodnotovou volbu, nikoliv objektivně správnější kritéria (s. 106). Buchanan naopak podkopává potřebu souhlasu lidu k zajištění legitimity státu a taktéž vyžaduje platný nárok na území. Stejně tak odmítá, že stačí rozhodnutí - nějaké - většiny k odtržení, zejména na 
základě argumentu, že se velká část populace takto stává nechtěnými občany jiného státu, což považuje za nedemokratické.

Závěrečná kapitola nabízí autorův shrnující a hodnotící komentář v komparativním pohledu, s důrazem na Buchananův př́stup. V úvodu kapitoly autor lehce shrnuje rozebírané prístupy, aby se pak zaměřil na komentár k jednotlivým kritériím vyplývajícím z jeho definice. Kapitola je doplněna o celou řadu př́kladů z politické praxe, což dává předchozí primárně normativně teoretické analýze čtivý charakter a přibližuje dané teorie laikům, kteří se na poli etických teorií tolik nepohybují.

Autor knihu uzavírá zodpovězením výzkumných otázek, které si vymezil v úvodu knihy a shrnuje: „Na základě komparace a výsledků následné analýzy a evaluace teorií na vytyčených kritériích se odvážím konstatovat, že etické argumenty Allena Buchanana, stejně jako analýza dalších teorií, vykazují závažné slabiny... [a]ni jedna $z$ těchto zkoumaných teorií sama o sobě neposkytuje univerzální etický návod na komplexní řešení morality secese“ (s. 139). Dle autora může být eticky nejudržitelnější hybridní teorie kombinující prvky teorie národního sebeurčení a plebiscitní teorie.

Za nejrozporuplněǰ̌ś část knihy považuji zejména výběr kritérií, která měla sloužit jako evaluativní nástroje pro určení etické hodnoty jednotlivých př́stupů. Z empirie a explanatorních teorií vyvozená definice měla sloužit jako normativní hledisko určující morální hodnotu dílčích prústupů. Samotná kritéria však nemají jasně daný normativní charakter, na jehož základě by se dala určit etická hodnota jednotlivých př́stupů. Mohou velmi dobře sloužit pro vytyčení dílčích rysů, na které se v komparaci zaměřit a které popsat, nepůsobí však jako „vnějšíc normativní hodnota, která by mohla rozhodnout o etické oprávněnosti jednoho z nich na úkor jiného.

Další moje výtka mírí na obsah poslední čtvrté kapitoly, která do značné míry pouze replikuje obsah kapitoly třetí. Mnohem zajímavější by bylo, kdyby se autor pokusil zmíněné teorie nějak obohatit, resp. překonat $\mathrm{v}$ tom duchu, který zmínil v závěru. Na druhou stranu je zřejmé, že se v této publikaci nejednalo o autorův záměr; o to více doufám, že se takového kroku dočkáme v autorově další knize.

Kniha Politický secesionismus a etické teorie: Allen Buchanan a jeho kritici - jak konstatoval autor v závěru - ukazuje bezzubost dosavadních (anglosaských) př́stupů na poli studia politické secese. Rozebírané př́stupy nereflektují vývoj na poli etické teorie poslední doby, který lze sledovat naprŕklad na poli kosmopolitní teorie a kosmopolitní demokracie. Zde se upouští od chápání normativní teorie jakožto expertního formulování sady pravidel a důrazu na institucionální a právní ukotvení, které by se pak mělo zvnějšku aplikovat na sociální realitu, a klade se mnohem větší dưraz na (emancipatornî) politickou a sociální praxi. ${ }^{2}$ Bude proto

2 Mezi jinými viz Ingram (2013); Nyers (2003); Leung (2013); Kurasawa (2004); Pieterse (2006); Jabri (2011); Mignolo (2000). 
zajímavé sledovat další výzkumné aktivity autora, konkrétně v tom ohledu, zdali bude teoretické úsilí na poli teorie secese sledovat obdobné trendy, resp. zdali se sám autor vydá obdobným směrem.

I přes výše zmíněné výhrady je recenzovaná kniha dozajista hodnotným prŕnosem pro českou politickou vědu a politickou teorii. Hodná doporučení je pro všechny, kdo při studiu secese usilují o překročení omezujících mantinelů explanatorních prístupư, stejně jako pro všechny milovníky přínosu politické filosofie a etiky pro politickou vědu.

\section{Literatura}

Ingram, James (2013): Radical Cosmopolitics the Etbics and Politics of Democratic Universalism. New York: Columbia University Press

Nyers, Peter. (2003): „Abject Cosmopolitanism: The Politics of Protection in the Antideportation Movement." Third World Quarterly 24(6): 1069-093. DOI: 10.1080/01436590310001630071

Leung, Gilbert (2013): „Cosmopolitan Ethics from Below.“ Ethical Pesrpectives 20(1): 43-60. DOI: 10.2143/EP.20.1.2965124

Kurasawa, Fuyuki (2004): „A Cosmopolitanism from Below: Alternative Globalization and Creation of a Solidarity without Bounds." European Journal of Sociology 45(2): 233-255. DOI: $10.1017 /$ S0003975604001444

Pieterse, Jan N. (2006): „Emancipatory Cosmopolitanism: Towards an Agenda.“ Development and Change 37(6): 1247-57. DOI: 10.1111/j.1467-7660.2006.00521.x

Jabri, Vivienne (2011): „Cosmopolitan Politics, Security, Political Subjectivity. “European Journal of International Relations 18(4): 625-644. DOI: 10.1177/1354066110397218

Mignolo, Walter (2000): „The Many Faces of Cosmo-polis: Border Thinking and Critical Cosmopolitanism.“ Public Culture 12(3): 721-748. DOI: 10.1215/08992363-12-3-721 